Carl Collins and Brian Klager, hydrographers, Wichita Field Office, sediment sampling above Cheney Reservoir, North Fork of Ninnescah River, July 6, 2010. Taken by Beatrice Ritchie, Wichifa Field Office.

\title{
Water Science Programs in Kansas
}

$\mathbf{T}$ he U.S. Geological Survey (USGS), an agency within the U.S. Department of the Interior, serves the Nation through its mission of providing reliable, unbiased scientific information on significant issues in which natural science can make a substantial contribution to the well being of the Nation and the world. USGS mission areas include: Climate and Land Use Change, Core Science Systems, Ecosystems, Energy, Minerals, and Environmental Health, Natural Hazards, Science Quality and Integrity, and Water (http://www.usgs.gov/start_with_science/). This information sheet highlights selected Water Science Programs in Kansas.

\section{Water Programs in Kansas have a long history}

The USGS has collected hydrologic information in Kansas since 1895 with the first USGS Cooperative Water Program funding agreement for 6 streamflow gages with the Kansas Water Board. USGS collects streamflow and gage-height data; reservoir content; water-quality and water-quantity data; suspended-sediment data; and groundwater levels. Hydrologic studies are conducted on national, regional, statewide, and local levels. The USGS in Kansas works cooperatively with 31 Federal, State, and local agencies, such as the Kansas Water Office, the U.S.Army Corps of Engineers, and the City of Wichita.

\section{Who and where are we?}

There are 72 USGS employees located across Kansas. The main water science center office and laboratory are in Lawrence and field offices are located in Hays and Wichita, Kansas.

\section{USGS Activities in Kansas}

\section{National Programs}

- Research into occurrence and movement of pesticides; antibiotics; and algal toxins, taste, and odor compounds in the environment

- Streamflow and water-quality data visualization

- Application of hydrologic modeling to USGS National Water-Quality Assessments

- Sediment research

- National evaluations of water use

\section{Statewide Programs}

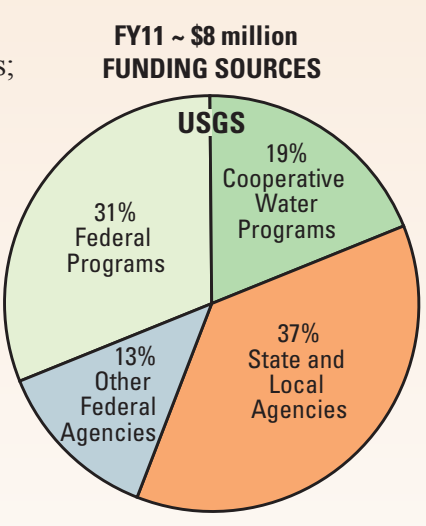

- Streamflow monitoring at more than 180 locations for flood forecasting, reservoir operations, and many other uses

- Monitoring of real-time water-quality conditions at 25 locations

- Assessment of sedimentation in Kansas reservoirs

- Compilation of Kansas municipal and irrigation water-use data

\section{Streamflow Information}

Continuous real-time streamflow information is a vital Kansas asset that can safeguard lives and property and ensures adequate water resources for a healthy State economy. The USGS operates more than 180 streamflow-monitoring stations in Kansas. Most of these stations are cooperatively funded in partnerships with local, tribal, State, and other Federal agencies. The USGS real-time water-monitoring network provides long-term, accurate, and impartial information that meets the needs of customers. This was particularly evident during the 2000-2006 drought and the 2007 floods.

http://waterdata.usgs.gov/ks/nwis/rt

USGS STREAMFLOW, LAKE-ELEVATION, AND WATER-QUALITY GAGES

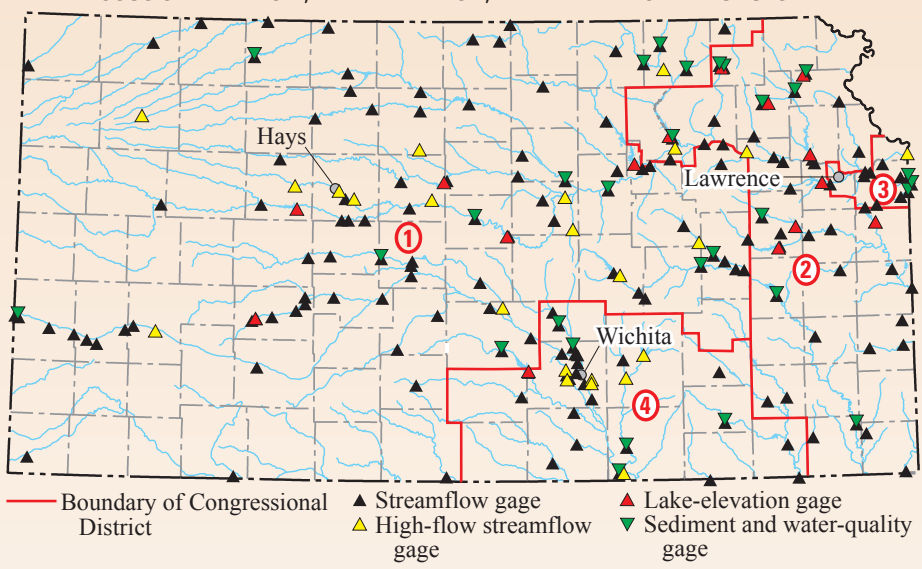

\section{Uses of Continuous Real-time Streamflow Information}

- State and local water-management and supply agencies - to plan, monitor, regulate, and adjust water withdrawals

- National Weather Service River Forecast Centers-to determine flood stages for various streams and to help forecast when and where streams will crest during floods

- U.S. Army Corps of Engineers - to most efficiently schedule reservoir releases

- Kansas Department of Transportation - to safely and efficiently design bridges, highways, and culverts that will convey sufficient streamflow so that roadways and bridges remain above water during flooding and escape structural damage

- Federal Emergency Management Agency - to delineate flood-prone areas, develop flood-insurance rates, and address emergencyresponse needs before, during, and after flooding

- Fishermen, swimmers, and boaters - to monitor water conditions for safe, optimum recreational use 


\section{Sediment Science in Kansas}

In Kansas and the rest of the United States, sediment is a concern for many reasons. Problems caused by sediment include degraded water quality and aquatic habitat, increased water-treatment costs, decreased channel capacity and degradation, and loss of water-storage capacity in reservoirs. Sediment serves as a carrier for various contaminants such as nutrients (nitrogen and phosphorus) and can sometimes be a source of contaminants to water and biota. Loss in reservoir waterstorage capacity led the State of Kansas through the Kansas Water Plan to begin a Reservoir Sustainability Initiative to preserve water-supply storage in reservoirs for as long as possible. Scientists study sediment transport from watersheds and river channels and how these affect the accumulation of sediment in reservoirs. This is important to understand because accumulation can lead to algal blooms and other water-quality issues. The USGS role in sediment science has been to determine storage capacity trends in sediment and water quality for reservoirs; sources of sediment, and operate a statewide monitoring network of stream sediment transport in cooperation with Federal, state, and local agencies. (http://www.kwo.org/Kansas\%20Water\%20Plan/ReservoirSustainability.htm)

\section{Key findings:}

- Reservoirs are filling with sediment at rates faster than designed and decreasing storage

- Streambanks are a substantial source of sediment to streams and downstream reservoirs

- Even with implementation of many best management practices, sediment transport from fields remain large

- In many reservoir watersheds, nutrients are transported with sediment and in some instances concentrations have increased with time. http://ks.water.usgs.gov/studies/sedsci/

\section{City of Wichita Water Supply}

In 1995, the City of Wichita determined the projected city water needs would not be met into the 21 st century. To meet future water demands, the City began the Aquifer Storage and Recovery (ASR) project to artificially recharge the Equus Beds. The ASR project, coupled with greater use of Cheney Reservoir - the city's existing surface water supply - will help Wichita provide water for more than 600,000 users by the year 2050. The project will be done in four phases, and will add up to 65 billion gallons of water to the aquifer as well as create a hydraulic barrier to slow down or stop the intrusion of saltwater into the groundwater supply. Phase 1 was completed in September 2006. The USGS role in the ASR project includes monitoring water quality changes, determining changes in the Equus Beds aquifer storage, and measuring streamflow availability for ASR use.

http://ks.water.usgs.gov/Kansas/studies/equus/

\section{Key findings:}

- Results of more than 6,500 samples indicate that the effects of artificial recharge on the water quality of the aquifer were minimal during the demonstration project from 1995 to 2000 with chloride, atrazine, and arsenic being of greatest concern

- Water storage in the Equus Beds aquifer has recovered more than half of lost storage volume since October 1992 largely because of decreased aquifer pumpage by Wichita and increased reliance on Cheney Reservoir for City of Wichita water supply

- An average of 174 days per year (1995-2008) had sufficient streamflow to meet permit requirements for recharging

- In 2005, chloride concentrations exceeded drinking water criteria of 250 parts-per-million in about 8 percent of the areas near Burrton and near the Arkansas River

- Between 1960 and 1992, chloride has moved about 3 miles from the saltwater contamination area near Burrton toward municipal and irrigation production wells. Chloride movement has slowed to less than 0.5 miles since 1992, because of water-level recoveries

\section{USGS Programs in Congressional Districts}

\section{Congressional District 1}

- Determination of water-quality conditions in Cheney Reservoir and watershed

- Determination of groundwater quality in the glacial till aquifer of northeast Kansas

\section{Congressional District 2}

- Monitoring of hydrologic conditions at Fort Riley

- Determination of groundwater quality in the glacial till aquifer of northeast Kansas

- Baseline sediment studies in Perry Lake watershed

- Determination of water-quality conditions on the Kickapoo Reservation

- Long-term monitoring of Cheney watershed and reservoir

- Sediment transport to and through Clinton Lake and sediment quality

- Sediment transport to and through Hillsdale Reservoir
- Ozark aquifer water availability and water quality

- John Redmond Reservoir sediment study

- Neosho River streambank stabilization study

\section{Congressional District 3}

- Effects of land use on biology of streams in Johnson County

- Effects of stormwater on water quality in Johnson County streams

- Effects of wastewater treatment facilities on Blue River and Indian Creek

- Sediment transport to and through Hillsdale Reservoir

\section{Congressional District 4}

- Determination of water-quality and quantity effects of Equus Beds aquifer recharge project

- Flood warning and inundation mapping on Cowskin Creek, Wichita 